\title{
Can we predict long-term survival in resectable pancreatic ductal adenocarcinoma?
}

\author{
Tamara M.H. Gall ${ }^{1}$, Gareth Gerrard ${ }^{2,3}$, Adam E. Frampton ${ }^{1}$, Leandro Castellano ${ }^{1}$, \\ Raida Ahmad ${ }^{4}$, Nagy Habib ${ }^{1}$, Duncan Spalding ${ }^{1}$, Madhava Pai ${ }^{1}$, Letizia Foroni ${ }^{4}$ and \\ Long R. Jiao ${ }^{1}$ \\ ${ }^{1}$ Department of Surgery and Cancer, Imperial College, Hammersmith Hospital Campus, London W12 0HS, United Kingdom \\ ${ }^{2}$ Faculty of Medicine, Imperial College, Hammersmith Hospital Campus, London W12 0HS, United Kingdom \\ ${ }^{3}$ Current address: Sarah Cannon Molecular Diagnostics, HCA Healthcare UK, London WC1E 6JA, United Kingdom \\ ${ }^{4}$ Department of Histopathology, Imperial College, Hammersmith Hospital Campus, London W12 0HS, United Kingdom \\ Correspondence to: Long R. Jiao, email: I.jiao@imperial.ac.uk \\ Keywords: PDAC; ion torrent; next-generation sequencing; nanostring; cell-free DNA
}

Received: December 02, $2018 \quad$ Accepted: December 12, $2018 \quad$ Published: January 22, 2019

Copyright: Gall et al. This is an open-access article distributed under the terms of the Creative Commons Attribution License 3.0 (CC BY 3.0), which permits unrestricted use, distribution, and reproduction in any medium, provided the original author and source are credited.

\section{ABSTRACT}

Objective: Pancreatic ductal adenocarcinoma (PDAC) is an aggressive tumour associated with poor 5-year survival. We aimed to determine factors which differentiate short and long-term survivors and identify a prognostic biomarker.

Methods: Over a ten-year period, patients with resected PDAC who developed disease recurrence within 12 months (Group I) and those who had no disease recurrence for 24 months (Group II) were identified. Clinicopathological data was analysed. Ion Torrent high-throughput sequencing on DNA extracted from FFPE tumour samples was used to identify mutations. Additionally, peripheral blood samples were analysed for variants in cell-free DNA, circulating tumour cells (CTCs), and microRNAs.

Results: Multivariable analysis of clinicopathological factors showed that a positive medial resection margin was significantly associated with short diseasefree survival $(p=0.007)$. Group I patients $(n=21)$ had a higher frequency of the KRAS mutant mean variant allele $(16.93 \% \pm 11.04)$ compared to those in Group II $(n=13 ; 7.55 \% \pm 5.76, p=0.0078)$. Group I patients also trended towards having a KRAS c.35G >A p.Gly12Asp mutation in addition to variants in other genes, such as TP53, CDKN2A, and SMAD4. Mutational status of cell-free DNA, and number of CTCs, was not found to be useful in this study. A circulating miRNA (hsa-miR-548ah-5p) was found to be significantly differentially expressed.

Conclusions: Medial resection margin status and the frequency of KRAS mutation in the tumour tissue are independent prognostic indicators for resectable PDAC. Circulating miRNA hsa-miR-548ah-5p has the potential to be used as a prognostic biomarker.

\section{INTRODUCTION}

Pancreatic ductal adenocarcinoma (PDAC) is an aggressive disease with an extremely poor prognosis. The GLOBOCAN project estimated that worldwide there are 337,872 new cases of PDAC diagnosed each year [1]. Although this only accounts for $3 \%$ of new cancer cases, it is the fourth leading cause of cancer death. Surgical resection is the only potentially curative treatment; however, even those with an R0 resection have a median survival of just 29 months [2]. Determining factors that lead to disease recurrence may help identify those with poor prognosis to allow personalised treatment options. Indeed, recent results from the Know Your 
Tumour Initiative, showed that survival is improved when matched therapy is given to patients with highly actionable proteomic alterations [3].

In 2008, an extensive land-mark study characterised the genetic network of PDAC [4]. It was established that four genes are most commonly affected in PDAC; predominately activating mutations in KRAS driving transformation, with concomitant loss-of-function mutations in CDKN2A, TP53 and SMAD4 associated with progression. There are a few published reports that KRAS mutational status is associated with shorter survival in PDAC patients [5, 6] Further, there is interest in developing prognostic biomarkers for PDAC, with the mutational status of cell-free DNA, the number of circulating tumour cells, and the expression of circulating microRNAs being of current interest to pancreatic cancer research [7]. We therefore aimed to establish whether any clinicopathological factors or genetic mutational differences existed between short and long disease-free survivors following surgical resection of PDAC. Further, we sought to identify a prognostic biomarker.

\section{RESULTS}

\section{Clinicopathological factors}

Over a 10-year period, 654 patients had pancreatic resections. Of these, 178 were for a histopathological diagnosis of PDAC, with 168 undergoing curative resections. The remaining 10 patients had locally advanced disease or metastatic disease evident intra-operatively. A further 16 patients had an R2 resection and were excluded from the analysis. Of the remaining 152 patients, 68 $(44.74 \%)$ had evidence of disease recurrence within 12 months of surgery (Group I) and 25 (16.45\%) had no evidence of disease recurrence for at least 24 months after surgery (Group II). These 93 patients were included in the analysis. Clinicopathological characteristics of the patients and tumours are shown in Table 1. There was no 30-day mortality. Complications occurred in 30.61\% with Clavien-Dindo classification 3a-4 complication [8]. occurring in 6 patients $(6.45 \%)$, four required radiological intervention for post-operative intra-abdominal collections and $2(2.15 \%)$ required further operations for bleeding from the pancreatic stump.

On univariate analysis, factors associated with short disease-free survival compared to long disease-free survival were: resection margin status $(p<0.001)$; medial resection margin status $(p<0.001)$, posterior resection margin status $(p=0.032)$, tumour size $(p=0.002)$; T-stage $(p=0.014)$; N-stage $(p=0.002)$; and the presence of lymphovascular invasion $(p=0.018)$ (Table 1). On multiple regression analysis, including these factors which significantly differed between the two groups, only medial resection margin status was independently associated with short disease-free survival ( $p=0.007$, OR $0.028,95 \%$ CI 0.002-0.383) (Table 2).

No patients included in this analysis were lost to follow-up following resection. Mean follow-up to date of death or to final follow-up for patients still alive was 24.8 months (range 1.5-108.1). By definition all the short disease-free survival group had disease recurrence. Nine $(36 \%)$ of the long disease-free survival group, developed disease recurrence after 24 months. Median overall survival was 9.8 months (95\% CI 9.010.6) for Group I (short disease-free survival) which was significantly less than the 56.1 months (95\% CI 34.4-77.8) for Group II (long disease-free survival; $p<0.001)$.

\section{Ion torrent sequencing}

\section{Technical performance of the ion ampliseq cancer hotspot panel v2}

DNA was extracted from macrodissection of tumour FFPE blocks in 34 patients. All samples (Group I $n=21$; Group II $n=13$ ) were processed once with an $81 \%$ success rate. Samples with poor sequence reads (amplicon drop-out or mean coverage $<100$ reads) were processed a second time. Successful results were generated in 18 patients from Group I and 11 patients from Group II. Mutations in 34 loci of 12 genes were identified as well as 382 single nucleotide polymorphisms (SNPs). The mean read length was $103 \mathrm{bp}$ with a mean of 197,452 reads per sample.

\section{KRAS mutations}

$17 / 18$ (94\%) of group I samples contained a KRAS point mutation. Of these: $70.59 \%$ were c. $35 \mathrm{G}>\mathrm{A}$ p.(Gly12Asp) (COSM521) and 17.65\% were c.35G $>$ T p.(Gly12Val) (COSM520). The mean frequency of the mutation found in each sample was $16.93 \pm 11.04 \%$. This compares to $11 / 11(100 \%)$ of group II samples, which contained a KRAS point mutation $(p=0.13)$. These were COSM521 in $45.45 \%(p=0.45)$, COSM520 in $27.27 \%$ ( $p$ $=0.65)$ and c.34G $>$ C p.(Gly12Arg) (COSM518) in $27.27 \%$ $(p=0.54)$. The mean frequency of the mutation found in each sample was $7.55 \pm 5.76 \%, p=0.0078$. See Figure 1 .

TP53, CDKNA2, SMAD4 and multiple mutations: Results summarized in Table 3. Interestingly, $61 \%$ of early recurrence patients compared to $27 \%$ of late recurrence patients $(p=0.12)$ had a KRAS mutation and a mutation in either TP53, CDKN2A or SMAD4. Of note, we are aware that some alterations in $C D K N 2 A$ may be missed due to large deletions not being picked up by the iontorrent method.

On regression analysis, both high frequency of $K R A S$ mutation and a positive medial resection margin, retain their significance $(p=0.002$ and $p=0.022$ respectively). 
Table 1: Clinicopathological characteristics of patients in Group I (early recurrence) and Group II (late recurrence) and $p$-value results of univariate analysis

\begin{tabular}{|c|c|c|c|c|}
\hline Characteristic & All patients $(n=93)$ & Group I $(n=68)$ & Group II $(n=25)$ & $p$ value \\
\hline $\begin{array}{l}\text { Median age } \\
\text { years (range) }\end{array}$ & $\begin{array}{c}66.66 \\
(40.71-82.82)\end{array}$ & $\begin{array}{c}66.18 \\
(40.71-82.82)\end{array}$ & $\begin{array}{c}67.81 \\
(49.63-75.36)\end{array}$ & 0.697 \\
\hline $\begin{array}{l}\text { Sex } \\
\text { M:F (\%) }\end{array}$ & $\begin{array}{c}52: 41 \\
(56: 44)\end{array}$ & $\begin{array}{c}35: 33 \\
(51: 49)\end{array}$ & $\begin{array}{c}17: 8 \\
(68: 32)\end{array}$ & 0.168 \\
\hline $\begin{array}{l}\text { Median preoperative } \\
\text { CA 19-9 } \\
\text { Kunits/L, (range) } \\
(n=54)\end{array}$ & $\begin{array}{c}87.00 \\
(1-32,876)\end{array}$ & $\begin{array}{c}73.00 \\
(1-32,876)\end{array}$ & $\begin{array}{c}198.00 \\
(1-10,195)\end{array}$ & 0.347 \\
\hline $\begin{array}{l}\text { Preoperative CA } 19-9 \\
<37:>37(\%) \\
(n=54)\end{array}$ & $\begin{array}{c}37: 17 \\
(69: 31)\end{array}$ & $\begin{array}{c}28: 9 \\
(76: 24)\end{array}$ & $\begin{array}{c}9: 8 \\
(53: 47)\end{array}$ & 0.121 \\
\hline $\begin{array}{l}\text { Median preoperative bilirubin } \\
\text { umol/L (range) } \\
(n=89)\end{array}$ & $\begin{array}{c}18 \\
(2-494)\end{array}$ & $\begin{array}{c}18 \\
(3-248)\end{array}$ & $\begin{array}{c}17 \\
(2-494)\end{array}$ & 0.877 \\
\hline $\begin{array}{l}\text { Preoperative bilirubin } \\
<22:>22(\%) \\
(n=89)\end{array}$ & $\begin{array}{c}52: 37 \\
(58: 42)\end{array}$ & $\begin{array}{c}39: 27 \\
(59: 41)\end{array}$ & $\begin{array}{c}13: 10 \\
(57: 43)\end{array}$ & 1.000 \\
\hline $\begin{array}{l}\text { Median preoperative CRP } \\
\mathrm{mg} / \mathrm{L} \text { (range) } \\
(n=89)\end{array}$ & $\begin{array}{c}6 \\
(1-141)\end{array}$ & $\begin{array}{c}6 \\
(1-141)\end{array}$ & $\begin{array}{c}6 \\
(1-141)\end{array}$ & 0.854 \\
\hline $\begin{array}{l}\text { Preoperative CRP } \\
<20:>20 \\
(n=89)\end{array}$ & $\begin{array}{c}66: 23 \\
(74: 26)\end{array}$ & $\begin{array}{c}48: 18 \\
(73: 27)\end{array}$ & $\begin{array}{c}18: 5 \\
(78: 22)\end{array}$ & 0.783 \\
\hline $\begin{array}{l}\text { Type of operation } \\
\text { PD:DP (\%) }\end{array}$ & $\begin{array}{c}81: 12 \\
(87: 13)\end{array}$ & $\begin{array}{c}58: 10 \\
(85: 15)\end{array}$ & $\begin{array}{c}23: 2 \\
(92: 8)\end{array}$ & 0.503 \\
\hline $\begin{array}{l}\text { Morbidity } \\
\text { no:yes }(\%) \\
(n=49)\end{array}$ & $\begin{array}{c}15: 34 \\
(31: 69)\end{array}$ & $\begin{array}{c}11: 24 \\
(31: 69)\end{array}$ & $\begin{array}{c}4: 10 \\
(29: 71)\end{array}$ & 1.000 \\
\hline $\begin{array}{l}\text { Differentiation } \\
\text { poor:moderate-to- } \\
\text { poor:moderate:well (\%) }\end{array}$ & $\begin{array}{c}55: 10: 27: 1 \\
(59: 11: 29: 1)\end{array}$ & $\begin{array}{c}40: 9: 18: 1 \\
(59: 13: 26: 1)\end{array}$ & $\begin{array}{c}15: 1: 9: 0 \\
(60: 4: 36: 0)\end{array}$ & 0.495 \\
\hline $\begin{array}{l}\text { Resection margin status } \\
\text { R0:R1 (\%) }\end{array}$ & $\begin{array}{l}45: 48 \\
(48: 52)\end{array}$ & $\begin{array}{c}25: 43 \\
(37: 63)\end{array}$ & $\begin{array}{c}20: 5 \\
(80: 20)\end{array}$ & 0.000 \\
\hline $\begin{array}{l}\text { Medial resection margin status } \\
\text { R0:R1 (\%) }\end{array}$ & $\begin{array}{c}57: 36 \\
(61: 39)\end{array}$ & $\begin{array}{c}33: 35 \\
(49: 51)\end{array}$ & $\begin{array}{l}24: 1 \\
(96: 4)\end{array}$ & 0.000 \\
\hline $\begin{array}{l}\text { Anterior resection margin status } \\
\text { R0:R1 }(\%)\end{array}$ & $\begin{array}{c}81: 12 \\
(87: 13)\end{array}$ & $\begin{array}{c}59: 9 \\
(87: 13)\end{array}$ & $\begin{array}{c}22: 3 \\
(88: 12)\end{array}$ & 1.00 \\
\hline $\begin{array}{l}\text { Posterior resection margin status } \\
\text { R0:R1 (\%) }\end{array}$ & $\begin{array}{c}81: 12 \\
(87: 13)\end{array}$ & $\begin{array}{c}56: 12 \\
(82: 18)\end{array}$ & $\begin{array}{c}25: 0 \\
(100: 0)\end{array}$ & 0.032 \\
\hline $\begin{array}{l}\text { Pancreatic resection margin } \\
\text { status } \\
\text { R0:R1 }(\%)\end{array}$ & $\begin{array}{c}86: 7 \\
(92: 8)\end{array}$ & $\begin{array}{c}65: 3 \\
(96: 4)\end{array}$ & $\begin{array}{c}21: 4 \\
(84: 16)\end{array}$ & 0.081 \\
\hline $\begin{array}{l}\text { Median tumour size } \\
\mathrm{cm} \text { (range) }\end{array}$ & $2.8(0.8-6.5)$ & $3.0(0.8-6.5)$ & $2.2(0.9-4.5)$ & 0.002 \\
\hline $\begin{array}{l}\text { T-stage } \\
1: 2: 3: 4(\%)\end{array}$ & $\begin{array}{c}3: 8: 63: 19 \\
(3: 9: 68: 20)\end{array}$ & $\begin{array}{c}3: 2: 47: 16 \\
(4: 3: 69: 24)\end{array}$ & $\begin{array}{c}0: 6: 16: 3 \\
(0: 24: 64: 12)\end{array}$ & 0.014 \\
\hline $\begin{array}{l}\text { N-stage } \\
\text { N0:N1 }(\%)\end{array}$ & $\begin{array}{c}22: 71 \\
(24: 76)\end{array}$ & $\begin{array}{c}10: 58 \\
(15: 85)\end{array}$ & $\begin{array}{c}12: 13 \\
(48: 52)\end{array}$ & 0.002 \\
\hline
\end{tabular}




\begin{tabular}{lcccc} 
Lymph node ratio & $21: 29$ & $18: 24$ & $3: 5$ & 1.000 \\
$<0.2:>0.2(\%)$ & $(42: 58)$ & $(43: 57)$ & $(38: 63)$ & \\
$(n=50)$ & & & & \\
Perineural invasion & $20: 73$ & $13: 55$ & $(28: 72)$ & 0.398 \\
absent:present (\%) & $(22: 78)$ & $(19: 81)$ & $10: 15$ & \\
Lymphovascular invasion & $21: 72$ & $11: 57$ & $(40: 60) 0.018$ & \\
absent:present (\%) & $(23: 77)$ & $(16: 84)$ & $2: 23$ & 0.338 \\
Adjuvant chemotherapy & $14: 79$ & $12: 56$ & $(8: 92)$ & \\
no:yes (\%) & $(15: 85)$ & $(18: 82)$ & $11: 14$ & $\mathbf{0 . 0 0 0}$ \\
Mortality & $14: 79$ & $3: 65$ & $(44: 56)$ & \\
no:yes (\%) & $(15: 85)$ & $(4: 96)$ & \\
\hline
\end{tabular}

Comparisons were made using Fisher's exact test for categorical data and the Wilcoxon signed rank test for continuous data. All tests were two-sided.

\section{Peripheral blood results}

\section{cfDNA sequencing}

Plasma samples from the peripheral circulation were collected from a total of sixteen patients ( 8 in Group I and 8 in Group II). A mean of $63.67 \pm 24.37 \mathrm{ng} / \mu \mathrm{l}$ of DNA was extracted from each sample. A genetic mutation was identified in two samples: an APC gene mutation and an STK11 mutation, the location of which corresponded to the tumour sample mutations seen in these patients. No other mutations, specifically no $K R A S$ mutations were identified in any samples.

\section{Circulating tumour cells (CTCs) analysis}

CTC analysis was undertaken from the peripheral circulation blood samples in sixteen patients (8 in Group I and 8 in Group II). Four patients (50\%) in Group I and 4 patients $(50 \%)$ in Group II had at least 1 CTC detected. No more than 2 CTCs were seen in any sample.

\section{microRNA nanoString analysis}

Blood from the sixteen patients used above was also analysed for miRNAs. The five miRNAs which were the most differentially expressed between patients with short disease-free survival and those with long disease-free survival were: hsa-miR-548ah5p; hsa-miR-550b-3p; hsa-miR-223-3p; hsa-let-7b$5 \mathrm{p}$ and hsa-let-7c. Three were downregulated and two upregulated in Group I compared to Group II. Only one of these miRNAs (hsa-miR-548ah-5p) was significantly differentially expressed between the two groups (Table 4). These miRNAs were entered into the MiRTarBase database. One of these differentially expressed miRNAs is known to target genes identified as mutated in the genetic sequencing of our PDAC samples, namely hsalet-7b-5p (target KRAS). None of these miRNAs have been previously identified as prognostic indicators in pancreatic cancer.

\section{DISCUSSION}

Over a ten-year period, our centre performed 152 curative resections for pancreatic ductal adenocarcinoma. Forty-five per cent developed disease recurrence within 12 months and $16 \%$ did not develop disease recurrence for at least two years. We investigated: clinicopathological factors; tumour DNA; and peripheral blood samples for cell-free DNA, circulating tumour cells and microRNAs; in order to identify predictors of long-term survival.

Although a number of clinicopathological factors were found to be associated with early recurrence on univariate analysis, only a positive medial resection margin was associated with early disease recurrence on multivariate analysis. This is consistent with several other retrospective trials which have previously identified resection margin status as an independent prognostic factor in PDAC patients [9-14]. In the European Study Group for Pancreatic Cancer-1 (ESPAC-1) study, those with an R1 resection status had a median survival of 10.9 months versus 16.9 months for patients with R0 margins [15].

We performed high-throughput DNA sequencing using the Ion Torrent multigene next generation sequencer on FFPE tumour samples. We identified that tumour samples from those with early recurrence had a higher frequency of $K R A S$ mutation than from those with late recurrence. A higher frequency of mutant KRAS may be related to increased tumour density, although this was not evaluated in the current study. Indeed, improved survival is seen in PDAC patients with tumour infiltrating lymphocytes [16] and, as lymphocytes may cause pancreatic tumour cell apoptosis, increased tumour density may reflect an absence of tumour infiltrating immune cells.

KRAS mutations were detected in $94 \%$ of the tumour samples from Group I (early recurrence) and $100 \%$ of tumour samples from Group II (late recurrence). This is repeatedly reported as the most commonly mutated gene in PDAC and, in agreement with others [17], we did not find that mutated $K R A S$ was a prognostic factor. However, notably, the long disease-free survivors had fewer patients 
Table 2: Multivariate analysis of clinicopathological factors that were significantly different between each group on univariate analysis

\begin{tabular}{lcccc}
\hline Characteristic & $\begin{array}{c}\boldsymbol{p} \text {-value univariate } \\
\text { analysis }\end{array}$ & $\begin{array}{c}\boldsymbol{p} \text {-value multivariate } \\
\text { analysis }\end{array}$ & $\mathbf{O R}$ & $\mathbf{9 5 \%}$ CI for OR \\
\hline $\begin{array}{l}\text { Resection margin status } \\
\text { Medial resection margin }\end{array}$ & 0.000 & 0.677 & 1.444 & $0.256-8.125$ \\
status & 0.000 & $\mathbf{0 . 0 0 7}$ & $\mathbf{0 . 0 2 8}$ & $\mathbf{0 . 0 0 2 - \mathbf { 0 . 3 8 3 }}$ \\
$\begin{array}{l}\text { Posterior resection margin } \\
\text { status }\end{array}$ & 0.032 & 0.998 & 0.000 & 0.000 \\
Tumour size & 0.002 & 0.132 & 0.593 & $0.301-1.170$ \\
T-stage & 0.014 & 0.556 & 1.324 & $0.520-3.372$ \\
N-stage & 0.002 & 0.124 & 0.370 & $0.104-1.313$ \\
Lymphovascular invasion & 0.018 & 0.229 & 0.418 & $0.101-1.734$ \\
\hline
\end{tabular}

Abbreviations: $\mathrm{OR}=$ Odds ratio. $\mathrm{CI}=$ Confidence interval.

with a COSM521 mutation and more patients with a COSM518. Although this result did not reach significance, it suggests that the type of KRAS mutation may have different effects on tumourigenesis. Indeed, an analysis of 27 PDAC tumour samples also suggested that those with a COSM521 mutation had worse survival than those with other KRAS mutations [18].

We identified TP53 mutations in $44 \%$ of tumour samples from the short disease-free survivors and $27 \%$ of those from the long disease-free survivors. This is in concordance with the literature where TP53 is repeatedly shown to be the second most commonly mutated gene in PDAC. Although the difference in mutational status between our two groups did not reach significance, it indicates a trend that patients with TP53 mutations have worse survival. Indeed, mutant TP53 has been associated with an increased chemoresistance to gemcitabine [19].

Considering each driver mutation in PDAC acts through differing pathways, we would expect multiple mutations to worsen tumourigenesis and link to survival. Particularly when the activating KRAS mutation, is in combination with a tumour suppressor gene. Certainly,

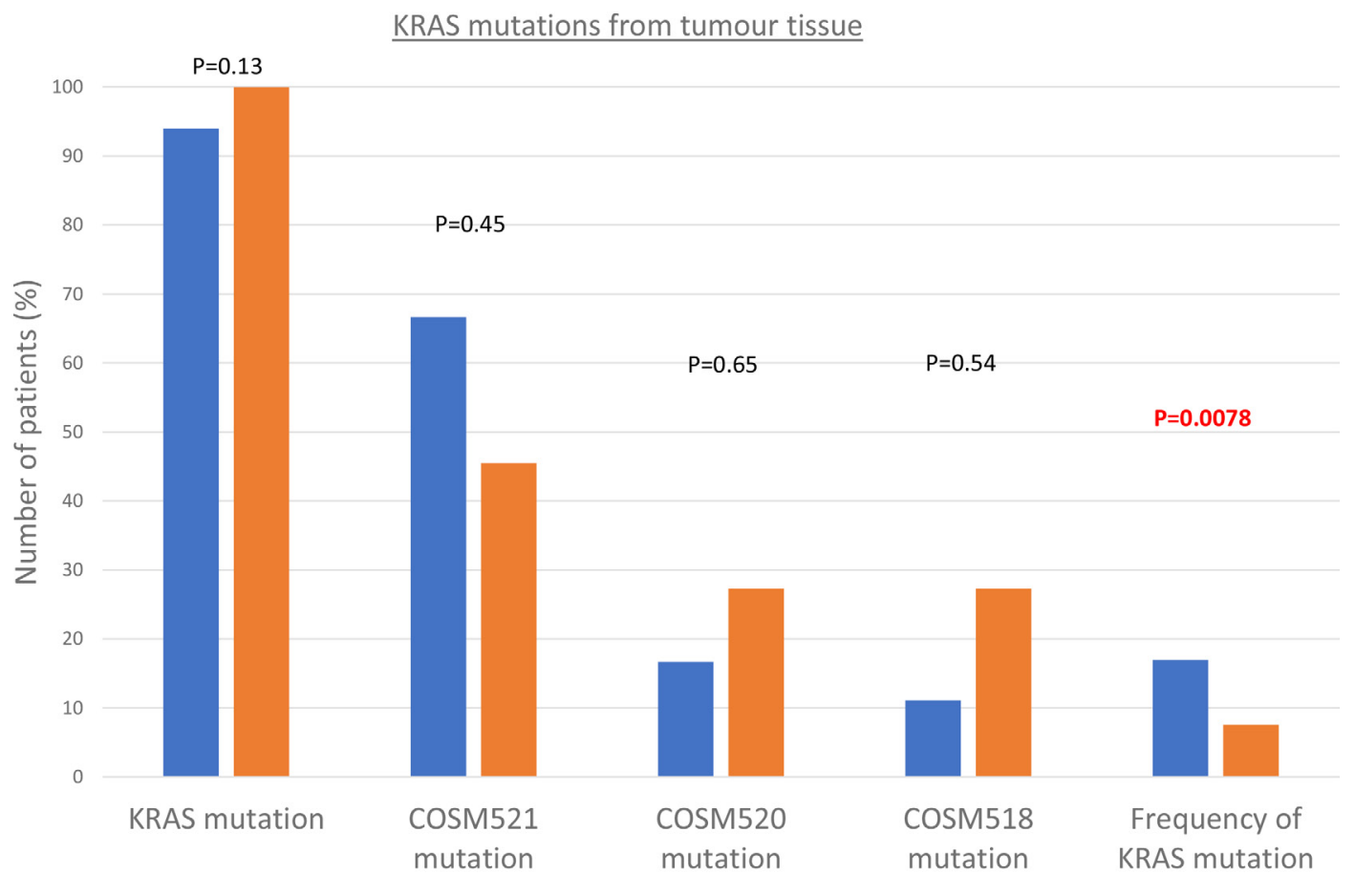

Group I (reccurrence $<12$ months), n=18 a Group II (no recurrence for 24 months), n=11

Figure 1: Results of next generation DNA sequencing. Shows the percentage of each type of KRAS gene mutation for Group I (early recurrence) and Group II (late recurrence). 
Table 3: Results of next generation DNA sequencing

\begin{tabular}{lccc}
\hline Gene mutation & Group I, $\boldsymbol{n}=\mathbf{1 8}$ & Group II, $\boldsymbol{n}=\mathbf{1 1}$ & $\boldsymbol{p}$ value \\
\hline TP53 & $8(44 \%)$ & $3(27 \%)$ & 0.86 \\
CDKN2A & $2(11 \%)$ & $0(0 \%)$ & 0.25 \\
SMAD4 & $2(11 \%)$ & $0(0 \%)$ & 0.25 \\
2 or more mutations & $11(61 \%)$ & $5(48 \%)$ & 0.41 \\
KRAS + TP53, CDKN2A or SMAD4 & $11(61 \%)$ & $3(27 \%)$ & 0.12 \\
\hline
\end{tabular}

Shows the number of TP53, CDKN2A, SMAD4 and multiple mutations for Group I (early recurrence) and Group II (late recurrence).

Table 4: The five most differentially expressed microRNAs between Group I and Group II

\begin{tabular}{lccccc}
\hline miRNA & Base mean & Log2 fold change & $\begin{array}{c}\text { Adjusted } \\
\boldsymbol{p} \text {-value }\end{array}$ & $\begin{array}{c}\text { Upregulated/downregulated } \\
\text { in Group I compared to } \\
\text { Group II }\end{array}$ & $\begin{array}{c}\text { PDAC gene } \\
\text { target }\end{array}$ \\
\hline $\begin{array}{l}\text { hsa-miR- } \\
\text { 548ah-5p }\end{array}$ & 42.63822508 & -0.712787648 & $\mathbf{0 . 0 0 1 7 2 8}$ & Down-regulated & Nil known \\
$\begin{array}{l}\text { hsa-miR- } \\
\text { 550b-3p }\end{array}$ & 46.53592309 & -0.61247248 & $\mathbf{0 . 2 4 5 3 2 6}$ & Down-regulated & Nil known \\
hsa-miR-223- & & & & Up-regulated & Nil known \\
3p & 155.6722423 & 0.603150078 & $\mathbf{0 . 0 8 0 4 0 9}$ & & \\
hsa-let-7b-5p & 60.40780961 & 0.607372968 & $\mathbf{0 . 0 8 5 1 3 4}$ & Up-regulated & KRAS \\
hsa-let-7c & 41.9846227 & -0.346058076 & $\mathbf{0 . 0 8 2 9 1 5}$ & Down-regulated & Nil known \\
\hline
\end{tabular}

when mouse models with activating $K R A S$ mutations are combined with a loss-of-function TP53 and/or $C D K N 2 A$ mutation, an acceleration of PDAC growth, more genetic instability and a tendency for poorly differentiated tumours is seen [20]. Although we found no significant differences between our two groups in terms of number of diver mutations identified, there was a trend towards more mutations in the short disease-free survival group. This is in agreement with others who have found worse survival in patients with concomitant $K R A S$ and $C D K N 2 A$ mutations [21], and the number of driver gene alterations has been found to be an independent prognostic factor for overall survival [22].

The Ion Torrent PGM sequencer has been used by others to detect mutations in cfDNA of patients with other tumour types [23-25] Genetic sequencing of blood DNA in our study did not reveal any mutations in the four driver genes associated with PDAC despite the Ion Torrent performing technically well. Interestingly the two gene variants were germline in STK11 and in APC, suggesting that these mutation defects may have been causative rather than resultant. Other studies have detected KRAS mutations in the blood of $33-54.5 \%$ of PDAC patients [26-31]. However, the majority of these investigated those with unresectable disease and thus at a later stage than our patient cohort. Patients who have resectable pancreatic cancer may have not yet shed tumour cells with DNA containing the mutational defect into the systemic circulation.
There were also no differences seen in the number of CTCs detected in the peripheral circulation between the early and late recurrence groups. We found CTCs in $50 \%$ of samples, similar to the literature, where CTCs have been detected in the blood of $43-80 \%$ of PDAC patients [32-34]. A shorter progression-free survival has previously been correlated with the detection of CTCs, however most of these studies were conducted in patients with unresectable disease. In a study conducted on patients with resectable PDAC, only $25 \%$ had detectable CTCs and, in agreement with our study, these patients did not have shorter disease-free survival [35]. Although the CellSearch system is the most commonly used for CTC detection, it may be that PDAC cells are not captured by this method. Indeed, it assumes that cancer cells have epithelial tissue by relying on the detection of cytokeratins 8-18- and 19-. However, some cancer cells undergo an epithelial-mesenchymal-transition (EMT), resulting in the downregulation of EpCAM and some cytokeratins [36]. EMT facilitates cancer invasion, so the known aggressive nature of PDAC would suggest that many of its cells undergo an early EMT. Newer technologies for CTC detection, including the ISET system and analysis of CTCs expressing tumour-initiating cell phenotype markers, has been shown to predict survival [37].

We identified five circulating miRNAs that were the most differentially expressed between patients with short- and those with long- disease free survivals. One of 
these was significantly differentially expressed (hsa-miR548ah-5p). Although none of these miRNAs have been previously reported as being of prognostic significance in PDAC, the let-7 family is known to target KRAS.

Lethal-7 (let-7) is able to regulate $R A S$ expression [38]. In cancer, members of the let-7 family are widely reported as tumour suppressor miRNAs with downregulation observed in many cancer types [39]. Reduced let-7 expression corresponds to elevated $R A S$ expression [40] and increased let-7 expression suppresses RAS and abolishes tumorigenesis [41, 42]. In PDAC, let-7 is up-regulated in normal ductal cells compared to PDAC cell-lines [43]. In cells with mutated $K R A S$, inhibition of cell proliferation was seen with the introduction of let-7a [43]. In human patients, Ali et al. [44], found that let-c and $\mathrm{d}$ were down-regulated in PDAC samples compared to samples from the normal pancreas. This supports our finding of down-regulated let-7c in the short disease-free survival group and a tumour suppressor role of let- $7 \mathrm{c}$ in PDAC. In contrast, Henry et al. [45] found let-7b to be up-regulated in the aspirate of cancerous cystic tumours, which supports our finding of up-regulated let-7b in the short disease-free survival group and an oncogenic role of let-7b in PDAC.

This was a limited study in terms of sample size and therefore subject to the effect small sample sizes have on extreme outcomes, putting our data at risk of a type II error. Further, PDACs exhibit tumour mutational heterogeneity and our tumour DNA was only extracted from one part of each patient's tumour.

\section{MATERIALS AND METHODS}

\section{Ethics}

This study was approved by a UK national research ethics committee (London; 09/H0722/77) and by our institutional review board (Hammersmith Hospital, Imperial Healthcare NHS Trust). Informed written patient consent for research was obtained before surgical treatment.

\section{Patients}

Patients who had a pancreatic resection over a ten-year period were included in our retrospectively created database. Inclusion factors were: patients with histopathologically confirmed pancreatic ductal adenocarcinoma (PDAC); patients who developed disease recurrence (either local or distant disease) within 12 months from surgery (Group I) or who had no disease recurrence for at least 24 months (Group II). A disease free interval of 12 months has been objectively determined to define early recurrence for resected PDAC [46]. Considering the CONKO-001 study [47] estimated that less than a quarter of resected PDAC patients survive 2 years, we used 24 months as an arbitrary cut-off for longterm disease free survival. Exclusion factors included: patients with abandoned resections (due to locally advanced disease or metastases seen intra-operatively); or R2 resections. Surgical decision was made at our hepatobiliary multidisciplinary team meeting. Surgery was offered to those with: absence of extrapancreatic disease; no involvement of the superior mesenteric artery (SMA); no encasement of the superior mesenteric vein (SMV) or portal vein $(\mathrm{PV})>180^{\circ}$; and fit to undergo major surgery (WHO performance status of $0-2$ ). For patients with local venous invasion with $<180^{\circ}$ encasement, resection and reconstruction of the SMV or PV was performed as required.

\section{Operative procedures}

All operations in our unit were performed by consultant hepatopancreatobiliary surgeons and have been previously described [48]. Both Whipple procedure and distal pancreatectomy with splenectomy are routinely performed either laparoscopically or as an open procedure. The pancreatico-enteric anastamosis was decided during the procedure by the surgeon and performed as either a pancreaticojejunostomy or pancreaticogastrostomy.

\section{Histopathological examination}

The examination of specimens was performed by a hepatopancreaticobiliary histopathologist according to the guidelines of the Royal College of Pathologists. Microscopic evidence of tumour involvement within $1 \mathrm{~mm}$ of the margin resulted in an R1 classification [49].

\section{Follow-up}

All patients had routine follow-up in the outpatient clinic at 3 monthly intervals for the first year and then six monthly intervals. Clinical examination, routine laboratory tests and CT scan was organised at each appointment. Date of disease recurrence was recorded as the date of the first CT scan to diagnose abnormal pathology. Date of death was determined from hospital and GP records. Disease-free and overall survival was defined as the interval between date of surgery and date of death or final follow-up.

\section{DNA high-throughput panel sequencing}

\section{Tumour samples}

The formalin-fixed paraffin-embedded (FFPE) blocks and corresponding H\&E stained slides for patients in Group I and Group II were collected. These were reviewed with a specialist pancreatic pathologist (RA) and areas of PDAC were marked. FFPE blocks corresponding to each H\&E slide were cut. Macrodissection of the tumour cells was then conducted. 


\section{DNA extraction from microdissected FFPE blocks}

The QIAamp DNA FFPE kit (Qiagen, Hilden, Germany) was used to extract genomic DNA from the FFPE tissues as per the manufacturer's instructions. DNA quantification of each sample was established with the Qubit 2.0 fluorometer (ThermoFisher, Massachusetts, USA) and the samples were stored at $4^{\circ} \mathrm{C}$.

\section{Ion torrent sequencing}

The Ion Torrent Personal Genome Machine (PGM) next generation sequencer (Life Technologies, Carlsbad, USA) $[24,50]$, was used to sequence the DNA for each sample according to the manufacturer's protocols. $10 \mathrm{ng}$ of DNA for each sample was used for library preparation with the Ion AmpliSeq Cancer Hotspot Panel v2 (Life Technologies) which covers 2,800 COSMIC notated mutations from 50 genes, including KRAS, CDKN2A, SMAD4 and TP53. Data analysis was carried out with Torrent Suite Software (Life Technologies).

\section{Blood samples}

Patients were invited to donate blood prior to their pancreatic resection. Blood was taken and processed as follows.

\section{For DNA sequencing}

An EDTA tube of whole blood was collected and DNA was extracted from the plasma using the QIAamp DNA Blood Mini Kit (Qiagen) according to the manufacturer's protocol. DNA quantification of each sample was established with the Qubit 2.0 fluorometer and the samples were stored at $-20^{\circ} \mathrm{C}$. Sequencing of DNA was carried out with the ion torrent next generation sequencer as described above.

\section{For circulating tumour cells (CTCs) analysis}

$7.5 \mathrm{mls}$ of whole blood was collected in a CellSave (Veridex, NJ, USA) preservative tube. The samples were then processed in our laboratory within 48 hours using the bead-based fluorescence CellSearch system (Veridex, NJ, USA) according to the manufacturer's protocol. Samples were then scanned on the CellTracks analyzer II fluorescent microscope (Veridex, NJ, USA). The cells were evaluated for CTCs independently by 2 operators.

\section{microRNA extraction}

Blood was collected into two EDTA tubes and immediately put on ice. After centrifugation, plasma was stored at $-80^{\circ} \mathrm{C}$. RNA extraction was performed at a later date using the miRNeasy serum/plasma kit (Qiagen) according to the maufacturer's protocol. RNA quantification was established with the NanoDrop 2000c UV-Vis spectrophotometer (ThermoFisher).

\section{microRNA analysis}

miRNA analysis of the extracted RNA was performed using the NanoString nCounter system (NanoString Technologies, Seattle, WA). The method measures a total of 800 probes. miRNA data analysis was performed using the nSolver software analysis, (nanoString Technologies, Seattle, USA). The serum miRNA profiling data was normalized using the average signals obtained from a spike-in control (Lyophilized C. elegans miR-39 miRNA mimic, Qiagen), and miRNAs that gave significant hybridization signals were used for downstream analysis.

\section{Statistical analysis}

The statistical analyses were performed using IBM SPSS statistics version 21 software package (IBM SPSS, Chicago, USA). The two groups consisted of those with disease recurrence within 12 months and those with no recurrence for at least 24 months. Univariate analysis comparisons were made using Fisher's exact test/Chi-squared test for categorical data and the mann whitney/ $t$-test - for continuous data. All tests were two-sided. Variables that were significantly different $(p<0.05)$ were included in a multiple regression analysis to examine the impact of these variables on early disease recurrence. Overall survival rates were calculated by Kaplan-Meier method and compared by the log-rank test.

\section{CONCLUSIONS}

A positive medial resection margin and a higher frequency of KRAS mutation in tumour tissue are independent prognostic indicators for resectable PDAC. Further, short disease-free survivors trended towards having a COSM521 mutation of KRAS and multiple mutations, particularly of p53, CKDKN2A, and SMAD4. Mutational status of cell-free DNA and CTCs were not found to be useful blood-based biomarkers in PDAC. However, the expression of a circulating microRNA - hsamiR-548ah-5p may differentiate between short and longterm survivors, which could lead to a more tailored and personalised management approach.

\section{CONFLICTS OF INTEREST}

None.

\section{FUNDING}

Alliance Family Foundation. 


\section{REFERENCES}

1. Ferlay J, Shin HR, Bray F, Forman D, Mathers C, Parkin DM. Estimates of worldwide burden of cancer in 2008: GLOBOCAN 2008. Int J Cancer. 2010; 127:2893-917. https://doi.org/10.1002/ijc.25516.

2. Gall TM, Thompson Z, Dinneen EP, Sodergren M, Pai M, Frampton AE, Jiao LR. Surgical techniques for improving outcomes in pancreatic ductal adenocarcinoma. Expert Rev Gastroenterol Hepatol. 2014; 8:241-46. https://doi.org/10. 1586/17474124.2014.881251.

3. Pishvaian MJ, Bender RJ, Halverson D, Rahib L, Hendifar AE, Mikhail S, Chung V, Picozzi VJ, Sohal D, Blais EM, Mason K, Lyons EE, Matrisian LM, et al. Molecular Profiling of Patients with Pancreatic Cancer: Initial Results from the Know Your Tumor Initiative. Clin Cancer Res. 2018; 24:5018-27. https:// doi.org/10.1158/1078-0432.CCR-18-2645.

4. Jones S, Zhang X, Parsons DW, Lin JC, Leary RJ, Angenendt P, Mankoo P, Carter H, Kamiyama H, Jimeno A, Hong SM, Fu B, Lin MT, et al. Core signaling pathways in human pancreatic cancers revealed by global genomic analyses. Science. 2008; 321:1801-06. https://doi. org/10.1126/science. 1164368 .

5. Schultz NA, Roslind A, Christensen IJ, Horn T, Høgdall E, Pedersen LN, Kruhøffer M, Burcharth F, Wøjdemann M, Johansen JS. Frequencies and prognostic role of KRAS and BRAF mutations in patients with localized pancreatic and ampullary adenocarcinomas. Pancreas. 2012; 41:759-66.

6. Sinn BV, Striefler JK, Rudl MA, Lehmann A, Bahra M, Denkert C, Sinn M, Stieler J, Klauschen F, Budczies J, Weichert W, Stenzinger A, Kamphues C, et al. KRAS mutations in codon 12 or 13 are associated with worse prognosis in pancreatic ductal adenocarcinoma. Pancreas. 2014; 43:578-83. https://doi.org/10.1097/ MPA.0000000000000077.

7. Gall TM, Frampton AE, Krell J, Castellano L, Jiao LR. Circulating molecular markers in pancreatic cancer: ready for clinical use? Future Oncol. 2013; 9:141-44. https://doi. org/10.2217/fon.12.187.

8. Dindo D, Demartines N, Clavien PA. Classification of surgical complications: a new proposal with evaluation in a cohort of 6336 patients and results of a survey. Ann Surg. 2004; 240:205-13. https://doi.org/10.1097/01. sla.0000133083.54934.ae

9. Jamieson NB, Chan NI, Foulis AK, Dickson EJ, McKay CJ, Carter CR. The prognostic influence of resection margin clearance following pancreaticoduodenectomy for pancreatic ductal adenocarcinoma. J Gastrointest Surg. 2013; 17:511-21.

10. Winter JM, Cameron JL, Campbell KA, Arnold MA, Chang DC, Coleman J, Hodgin MB, Sauter PK, Hruban RH, Riall TS, Schulick RD, Choti MA, Lillemoe KD, Yeo CJ. 1423 pancreaticoduodenectomies for pancreatic cancer: A single-institution experience. J Gastrointest Surg. 2006; 10: 1199-210. https://doi.org/10.1016/j.gassur.2006.08.018.
11. Trede M, Schwall G, Saeger HD. Survival after pancreatoduodenectomy. 118 consecutive resections without an operative mortality. Ann Surg. 1990; 211:44758. https://doi.org/10.1097/00000658-199004000-00011.

12. Gall FP, Kessler H, Hermanek P. Surgical treatment of ductal pancreatic carcinoma. Eur J Surg Oncol. 1991; 17:173-81.

13. Millikan KW, Deziel DJ, Silverstein JC, Kanjo TM, Christein JD, Doolas A, Prinz RA. Prognostic factors associated with resectable adenocarcinoma of the head of the pancreas. Am Surg. 1999; 65:618-23.

14. Wenger FA, Peter F, Zieren J, Steiert A, Jacobi CA, Müller JM. Prognosis factors in carcinoma of the head of the pancreas. Dig Surg. 2000; 17:29-35. https://doi. org/10.1159/000018797.

15. Neoptolemos JP, Stocken DD, Dunn JA, Almond J, Beger HG, Pederzoli P, Bassi C, Dervenis C, FernandezCruz L, Lacaine F, Buckels J, Deakin M, Adab FA, et al; European Study Group for Pancreatic Cancer. Influence of resection margins on survival for patients with pancreatic cancer treated by adjuvant chemoradiation and/or chemotherapy in the ESPAC-1 randomized controlled trial. Ann Surg. 2001; 234:758-68. https://doi. org/10.1097/00000658-200112000-00007.

16. Lianyuan T, Dianrong X, Chunhui Y, Zhaolai M, Bin J. The predictive value and role of stromal tumor-infiltrating lymphocytes in pancreatic ductal adenocarcinoma (PDAC). Cancer Biol Ther. 2018; 19:296-305. https://doi.org/10.108 0/15384047.2017.1416932.

17. Hruban RH, van Mansfeld AD, Offerhaus GJ, van Weering DH, Allison DC, Goodman SN, Kensler TW, Bose KK, Cameron JL, Bos JL. K-ras oncogene activation in adenocarcinoma of the human pancreas. A study of 82 carcinomas using a combination of mutant-enriched polymerase chain reaction analysis and allele-specific oligonucleotide hybridization. Am J Pathol. 1993; 143:545-54.

18. Miglio U, Oldani A, Mezzapelle R, Veggiani C, Paganotti A, Garavoglia M, Boldorini R. KRAS mutational analysis in ductal adenocarcinoma of the pancreas and its clinical significance. Pathol Res Pract. 2014; 210:307-11. https:// doi.org/10.1016/j.prp.2014.01.011.

19. Fiorini C, Cordani M, Padroni C, Blandino G, Di Agostino S, Donadelli M. Mutant p53 stimulates chemoresistance of pancreatic adenocarcinoma cells to gemcitabine. Biochim Biophys Acta. 2015; 1853:89-100. https://doi.org/10.1016/j. bbamcr.2014.10.003.

20. Morris JP 4th, Wang SC, Hebrok M. KRAS, Hedgehog, Wnt and the twisted developmental biology of pancreatic ductal adenocarcinoma. Nat Rev Cancer. 2010; 10:683-95. https://doi.org/10.1038/nrc2899.

21. Rachakonda PS, Bauer AS, Xie H, Campa D, Rizzato C, Canzian F, Beghelli S, Greenhalf W, Costello E, Schanne M, Heller A, Scarpa A, Neoptolemos JP, et al. Somatic mutations in exocrine pancreatic tumors: association with 
patient survival. PLoS One. 2013; 8:e60870. https://doi. org/10.1371/journal.pone.0060870.

22. Iacobuzio-Donahue $\mathrm{CA}, \mathrm{Fu} \mathrm{B}$, Yachida S, Luo M, Abe H, Henderson CM, Vilardell F, Wang Z, Keller JW, Banerjee P, Herman JM, Cameron JL, Yeo CJ, et al. DPC4 gene status of the primary carcinoma correlates with patterns of failure in patients with pancreatic cancer. J Clin Oncol. 2009; 27:1806-13. https://doi.org/10.1200/JCO.2008.17.7188.

23. Vaca-Paniagua F, Oliver J, Nogueira da Costa A, Merle P, McKay J, Herceg Z, Holmila R. Targeted deep DNA methylation analysis of circulating cell-free DNA in plasma using massively parallel semiconductor sequencing. Epigenomics. 2015; 7:353-62. https://doi.org/10.2217/ epi.14.94.

24. McClure R, Mai M, McClure S. High-throughput sequencing using the Ion Torrent personal genome machine for clinical evaluation of somatic hypermutation status in chronic lymphocytic leukemia. J Mol Diagn. 2015; 17:14554. https://doi.org/10.1016/j.jmoldx.2014.11.006.

25. Rothé F, Laes JF, Lambrechts D, Smeets D, Vincent D, Maetens M, Fumagalli D, Michiels S, Drisis S, Moerman C, Detiffe JP, Larsimont D, Awada A, et al. Plasma circulating tumor DNA as an alternative to metastatic biopsies for mutational analysis in breast cancer. Ann Oncol. 2014; 25:1959-65. https://doi.org/10.1093/annonc/mdu288.

26. Kinugasa H, Nouso K, Miyahara K, Morimoto Y, Dohi C, Tsutsumi K, Kato H, Matsubara T, Okada H, Yamamoto $\mathrm{K}$. Detection of K-ras gene mutation by liquid biopsy in patients with pancreatic cancer. Cancer. 2015; 121:2271-80. https://doi.org/10.1002/cncr.29364.

27. Däbritz J, Preston R, Hänfler J, Oettle H. K-ras mutations in the plasma correspond to computed tomographic findings in patients with pancreatic cancer. Pancreas. 2012; 41:323-25. https://doi.org/10.1097/MPA.0b013e3182289118.

28. Chen H, Tu H, Meng ZQ, Chen Z, Wang P, Liu LM. K-ras mutational status predicts poor prognosis in unresectable pancreatic cancer. Eur J Surg Oncol. 2010; 36:657-62. https://doi.org/10.1016/j.ejso.2010.05.014.

29. Uemura T, Hibi K, Kaneko T, Takeda S, Inoue S, Okochi O, Nagasaka T, Nakao A. Detection of K-ras mutations in the plasma DNA of pancreatic cancer patients. J Gastroenterol. 2004; 39:56-60. https://doi.org/10.1007/ s00535-003-1245-1.

30. Dai MH, Zhao YP, Cai LX, Zhu Y. [Combined detection of K-ras mutation and CA 19-9 level in plasma of patients with pancreatic cancer]. [Article in Chinese]. Zhonghua Wai Ke Za Zhi. 2003; 41:332-35.

31. Maire F, Micard S, Hammel P, Voitot H, Lévy P, Cugnenc PH, Ruszniewski P, Puig PL. Differential diagnosis between chronic pancreatitis and pancreatic cancer: value of the detection of KRAS2 mutations in circulating DNA. Br J Cancer. 2002; 87:551-54. https://doi.org/10.1038/ sj.bjc. 6600475 .

32. Ren C, Han C, Zhang J, He P, Wang D, Wang B, Zhao $\mathrm{P}$, Zhao X. Detection of apoptotic circulating tumor cells in advanced pancreatic cancer following 5-fluorouracil chemotherapy. Cancer Biol Ther. 2011; 12:700-06. https:// doi.org/10.4161/cbt.12.8.15960.

33. de Albuquerque A, Kubisch I, Breier G, Stamminger G, Fersis N, Eichler A, Kaul S, Stölzel U. Multimarker gene analysis of circulating tumor cells in pancreatic cancer patients: a feasibility study. Oncology. 2012; 82:3-10. https://doi.org/10.1159/000335479.

34. Han L, Chen W, Zhao Q. Prognostic value of circulating tumor cells in patients with pancreatic cancer: a metaanalysis. Tumour Biol. 2014; 35:2473-80. https://doi. org/10.1007/s13277-013-1327-5.

35. Bissolati M, Sandri MT, Burtulo G, Zorzino L, Balzano G, Braga M. Portal vein-circulating tumor cells predict liver metastases in patients with resectable pancreatic cancer. Tumour Biol. 2015; 36:991-96. https://doi.org/10.1007/ s13277-014-2716-0.

36. Müller V, Alix-Panabières C, Pantel K. Insights into minimal residual disease in cancer patients: implications for anti-cancer therapies. Eur J Cancer. 2010; 46:1189-97. https://doi.org/10.1016/j.ejca.2010.02.038.

37. Poruk KE, Blackford AL, Weiss MJ, Cameron JL, He J, Goggins M, Rasheed ZA, Wolfgang CL, Wood LD. Circulating Tumor Cells Expressing Markers of Tumor-Initiating Cells Predict Poor Survival and Cancer Recurrence in Patients with Pancreatic Ductal Adenocarcinoma. Clin Cancer Res. 2017; 23:2681-90. https://doi.org/10.1158/1078-0432.CCR-16-1467.

38. Johnson SM, Grosshans H, Shingara J, Byrom M, Jarvis R, Cheng A, Labourier E, Reinert KL, Brown D, Slack FJ. RAS is regulated by the let-7 microRNA family. Cell. 2005; 120:635-47. https://doi.org/10.1016/j.cell.2005.01.014.

39. Büssing I, Slack FJ, Grosshans H. let-7 microRNAs in development, stem cells and cancer. Trends Mol Med. 2008; 14:400-09. https://doi.org/10.1016/j.molmed.2008.07.001.

40. Takamizawa J, Konishi H, Yanagisawa K, Tomida S, Osada H, Endoh H, Harano T, Yatabe Y, Nagino M, Nimura Y, Mitsudomi T, Takahashi T. Reduced expression of the let-7 microRNAs in human lung cancers in association with shortened postoperative survival. Cancer Res. 2004; 64:3753-56. https://doi.org/10.1158/0008-5472. CAN-04-0637.

41. Kumar MS, Erkeland SJ, Pester RE, Chen CY, Ebert MS, Sharp PA, Jacks T. Suppression of non-small cell lung tumor development by the let-7 microRNA family. Proc Natl Acad Sci U S A. 2008; 105:3903-08. https://doi. org/10.1073/pnas.0712321105.

42. Yu F, Yao H, Zhu P, Zhang X, Pan Q, Gong C, Huang Y, Hu $\mathrm{X}, \mathrm{Su} \mathrm{F}$, Lieberman J, Song E. let-7 regulates self renewal and tumorigenicity of breast cancer cells. Cell. 2007; 131:1109-23. https://doi.org/10.1016/j.cell.2007.10.054.

43. Torrisani J, Bournet B, du Rieu MC, Bouisson M, Souque A, Escourrou J, Buscail L, Cordelier P. let-7 MicroRNA transfer in pancreatic cancer-derived cells inhibits in vitro 
cell proliferation but fails to alter tumor progression. Hum Gene Ther. 2009; 20:831-44. https://doi.org/10.1089/ hum.2008.134.

44. Ali S, Saleh H, Sethi S, Sarkar FH, Philip PA. MicroRNA profiling of diagnostic needle aspirates from patients with pancreatic cancer. Br J Cancer. 2012; 107:1354-60. https:// doi.org/10.1038/bjc.2012.383.

45. Henry JC, Bassi C, Giovinazzo F, Bloomston M. MicroRNA from pancreatic duct aspirate differentiates cystic lesions of the pancreas. Ann Surg Oncol. 2013; 20:S661-66. https:// doi.org/10.1245/s10434-013-3138-8.

46. Groot VP, Gemenetzis G, Blair AB, Rivero-Soto RJ, Yu J, Javed AA, Burkhart RA, Rinkes IH, Molenaar IQ, Cameron JL, Weiss MJ, Wolfgang CL, He J. Defining and Predicting Early Recurrence in 957 Patients With Resected Pancreatic Ductal Adenocarcinoma. Ann Surg. 2018 Mar 23. https:// doi.org/10.1097/SLA.0000000000002734. [Epub ahead of print].

47. Oettle H, Post S, Neuhaus P, Gellert K, Langrehr J, Ridwelski K, Schramm H, Fahlke J, Zuelke C, Burkart C, Gutberlet K, Kettner E, Schmalenberg H, et al. Adjuvant chemotherapy with gemcitabine vs observation in patients undergoing curative-intent resection of pancreatic cancer: a randomized controlled trial. JAMA. 2007; 297:267-77. https://doi.org/10.1001/jama.297.3.267.

48. Sommerville CA, Limongelli P, Pai M, Ahmad R, Stamp G, Habib NA, Williamson RC, Jiao LR. Survival analysis after pancreatic resection for ampullary and pancreatic head carcinoma: an analysis of clinicopathological factors. J Surg Oncol. 2009; 100:651-56. https://doi.org/10.1002/ jso. 21390 .

49. Campbell F, Smith RA, Whelan P, Sutton R, Raraty M, Neoptolemos JP, Ghaneh P. Classification of R1 resections for pancreatic cancer: the prognostic relevance of tumour involvement within $1 \mathrm{~mm}$ of a resection margin. Histopathology. 2009; 55:277-83. https://doi. org/10.1111/j.1365-2559.2009.03376.x.

50. Belardinilli F, Capalbo C, Buffone A, Petroni M, Colicchia V, Ferraro S, Zani M, Nicolussi A, D’Inzeo S, Coppa A, Screpanti I, Gulino A, Giannini G. Validation of the Ion Torrent PGM sequencing for the prospective routine molecular diagnostic of colorectal cancer. Clin Biochem. 2015; 48:908-10. https://doi.org/10.1016/j. clinbiochem.2015.04.003. 